\title{
ESCENARIOS DE LA DISTRIBUCIÓN POTENCIAL DE Pinus patula Schltdl. et Cham. Y Pinus pseudostrobus Lindl. CON MODELOS DE CAMBIO CLIMÁTICO EN EL ESTADO DE MÉXICO
}

\author{
POTENTIAL DISTRIBUTION SCENARIOS OF Pinus patula Schltdl. et Cham. AND \\ Pinus pseudostrobus Lindl. IN THE STATE OF MEXICO UNDER CLIMATE CHANGE MODELS
}

\author{
Ramiro Pérez Miranda', Francisco Moreno Sánchez', Antonio González Hernández’ y Víctor Arreola Padilla
}

\section{RESUMEN}

Las repercusiones del cambio climático (CC) en el desarrollo de la flora modificarán la distribución espacial de los ecosistemas forestales. Algunas especies migrarán hacia mayores altitudes y a otras latitudes, por lo que desaparecerán total o parcialmente de su área original. El objetivo del estudio que se describe consistió en comparar la distribución potencial actual de Pinus patula y de Pinus pseudostrobus bajo escenarios de CC con modelos de circulación general (MCG) de la atmósfera y con Ensamble regional (Er) de MCG. Para 2030, el área de P. patula con escenarios de CC A2 calculada mediante GFDL 2.0 tuvo 10705 ha más de superficie de aptitud alta que HADGEM, mientras que el Er de MCG fue mayor, con 84926 ha que GFDL. Respecto a 2050, esta aptitud con GFDL 2.0 registró mayor territorio que HADGEM, con 20482 ha; el Er de MCG fue más alto con 62954 ha que GFDL 2.O. Para 2030, el GFDL 2.0 de P. pseudostrobus determinó siete hectáreas más de aptitud alta que HADGEM; por el contrario, el Er de MCG fue superior, con 86555 ha que GFDL 2.0. Para 2050, mediante este último, la cifra es más grande que con HADGEM, por 264 ha; el Er de MCG resultó con 84457 ha que a través de GFDL 2.0. La distribución potencial de los dos taxa en el Estado de México con escenarios de CC tiende a reducir su superficie. Los escenarios de Ensamble de MCG permiten generar resultados aplicados con más detalle que los MCG.

Palabras clave: Distribución potencial, escenarios de cambio climático, modelos de circulación general (MCG), Pinus patula Schltdl. et Cham., Pinus pseudostrobus Lindl., SIG.

\begin{abstract}
The impacts of climate change (CC) in the development of flora change the spatial distribution of forest ecosystems. Some migrate to higher altitudes and elsewhere, so these species disappear totally or partially of its geographical area. The objective of the study was to compare the current potential distribution of P. patula and P. pseudostrobus under CC scenarios with general circulation models (GCMs) of the atmosphere and Regional assembly (Ra) of the MCG. The distribution of P. patula with CC scenarios A2 2030, the GFDL model was 10705 has more surface area that HADGEM high fitness, while the Ra GCM was higher with 84926 ha GFDL. By 2050, this ability to GFDL 20 was higher HADGEM surface with 20482 ha; meantime the GCM Ra was highest with 62.954 ha GFDL 20. The P. pseudostrobus 2030, the GFDL 2.0 had seven hectares of high fitness surface that HADGEM, however the GCM Ra was higher with 86555 ha GFDL 2.0. By 2050, with GFDL 2.0 HADGEM was higher compared with 264 ha Ra GCM was higher with 84457 ha GFDL 2.0. The potential distribution of the two species in the State of Mexico with CC scenarios tends to reduce its distribution area. Assemblies scenarios GCM applied to generate results allow greater detail than GCM.
\end{abstract}

Key words: Potential distribution, climate change scenarios, general circulation models (GCMs), Pinus patula Schltdl. et Cham., Pinus pseudostrobus Lindl., GIS.

Fecha de recepción: 9 de julio de 2012.

Fecha de aceptación: 19 de diciembre de 2012.

'Centro Nacional de Investigación Disciplinaria en Conservación y Mejoramiento de Ecosistemas Forestales. INFAP.Correo-e: perez.ramiro@inifap.gob.mx. 


\section{INTRODUCCIÓN}

Cada vez más la sociedad demanda diversos insumos y productos para su desarrollo económico. Esto ha ocasionado alteraciones en la vida terrestre, lo cual se refleja en cambios en los paisajes y sistemas naturales en escalas diferentes. El cambio climático es un fenómeno atribuido a factores antrópicos (PNUMA, 2005; IPCC, 2007) y sus efectos son varios: alteraciones en el nivel del mar, derretimiento de glaciares y eventos extremos como sequías e inundaciones, escasez de agua y productos agropecuarios, propagación de enfermedades humanas, de la fauna y de la flora transmitidas por vectores biológicos y físicos, entre otros (UNFCCC, 2007).

El cambio climático puede afectar a los bosques de formas distintas alterando la frecuencia, la intensidad, la duración y el ritmo de incendios, sequías, daños fitosanitarios, huracanes, etcétera. (Dale et al., 2001). En la biodiversidad se modifican, directamente, los niveles de organización, desde individuos hasta poblaciones y de comunidades a ecosistemas (Root et al., 2003). Los escenarios de cambio climático indican que un incremento de la temperatura propiciará la expansión de los bosques en latitudes altas, mientras que en latitudes medias se espera un decremento o migración de poblaciones hacia zonas con climas más adecuados a su desarrollo (Sims et al., 2007). En general, las zonas cálidas y húmedas promueven el desarrollo de los bosques y, en contraste, regiones cálidas y secas crean un déficit de humedad, que resulta en una sustitución de zonas forestales por pastizales (Sedjo, 2010).]

Ante los efectos del cambio climático es importante considerar medidas de adaptación y mitigación por parte del sector forestal; para ello, las evaluaciones sobre las consecuencias a corto y largo plazo aportarán información para diseñarlas y aplicarlas (Spittlehouse y Stewart, 2003). Una de estas evaluaciones se refiere a la aplicación de modelos de simulación de la atmósfera de cambios en variables climáticas, a partir de las cuales se obtienen variables base para realizar simulaciones a futuro respecto al comportamiento y desarrollo de especies, ecosistemas y sistemas de producción agrícola, ganadera, silvícola, entre otras (Magaña et al., 2000; Gómez et al., 2007). En México, estos trabajos son relevantes, ya que tiene un territorio megadiverso y cuenta con numerosas especies vegetales y animales endémicas, algunas de las cuales están en peligro de extinción (Trejo et al., 2011).

Los estudios de modelación de cambio climático en el ámbito internacional son varios, entre ellos destaca el de Iverson et al. (1999), quienes usaron modelos determinísticos de regresión y de migración estocásticos con la finalidad de examinar la distribución potencial de Pinus virginiana Mill. en Estados Unidos de América, bajo un escenario de cambio climático $2 \mathrm{X} \mathrm{CO}_{2}$; los resultados indican afectaciones severas en zonas de migración en regiones con mayor fragmentación cuando la abundancia era baja. En Ecuador, Delgado y Suárez (2009) utilizaron el modelo de circulación general HadCM3-A2 para determinar la distribución potencial

\section{INTRODUCTION}

Society is increasingly demanding diverse inputs and products for its economic development. This has altered life on land, which is reflected in the landscape and natural system changes at different scales. Climate change is a phenomenon attributed to anthropic factors (PNUMA, 2005; IPCC, 2007) with several effects: changes in sea level, melting of glaciers, and extreme events, such as droughts and floods, water scarcity, lack of agriculture and livestock products, propagation of human, animal and plant diseases transmitted by physical and biological factors, among others (UNFCCC, 2007).

Climate change may affect forests in diverse ways, thus altering frequency, intensity, duration and rhythm of wildfires, draughts, phytosanitary damage, hurricanes, etc. (Dale et al., 2001). In the case of biodiversity, organization levels are directly modified, from individuals to populations, from single communities to entire ecosystems (Root et al., 2003). Climate change scenarios indicate that an increment of temperature will cause the expansion of forests in high latitudes, whereas the expectation in medium latitudes is a decrease or migration of populations towards zones more suitable for their development (Sims et al., 2007). In general terms, warm and humid zones promote the development of forests, and, in turn, warm and dry regions produce a lack of humidity, which results in a transformation of forest zones into pastures (Sedjo, 2010).

Given the effects of climate change, it is important that the forest sector considers adaptation and mitigation measures. In order to do so, evaluations of the short and long-term consequences will provide information for their design and application (Spittlehouse and Stewart, 2003). One of these evaluations conveys the application of simulation models of climate change of the atmosphere variables, which provide basic variables for making future simulations regarding the behavior and development of species, ecosystems and agriculture, livestock, forest and other kind of systems (Magaña, 2000; Gómez et al., 2007). These works are relevant in Mexico, considering it is a megadiverse territory with numerous endemic vegetable and animal species, some of which are endangered (Trejo et al., 2011).

There are several international climate change modeling studies, but it should be highlighted that of Iverson et al. (1999), who used deterministic models of estocastic regression and migration to examine the potential distribution of Pinus virginiana Mill. in the United States, under a $2 \mathrm{X} \mathrm{CO}_{2}$ climate change scenario; results indicate severe affectations in migration areas in regions with a higher fragmentation when abundance was low. In Ecuador, Delgado and Suárez (2009) used the HadCM3-A2 general circulation model to determine the potential distribution of 413 vegetable species for 2080 . Such species tend to colonize higher altitudes, which would modify the structure of current ecosystems. Zonneveld et al. (2009) did a research in Southeastern Asia for 
de 413 especies vegetales para 2080. La tendencia de las especies es colonizar altitudes más elevadas, lo cual modificaría la estructura de los ecosistemas actuales. Zonneveld et al. (2009) efectuaron una investigación en Asia sudoriental a fin de predecir la distribución de Pinus kesiya Royle ex Gordon y P. merkusii Jungh \& de Vriese para 2050, con los modelos de circulación general HADCM3 y CCCMA; se espera que ambas especies se favorezcan con el cambio climático conforme existan nuevos lugares con las condiciones idóneas para su establecimiento a mayores altitudes. Pérez et al. (2011) estudiaron los hábitats subalpino y alpino conformado por bosques de P. uncinata Miller, matorrales y pastos; los resultados pronostican para estos hábitats un aumento en la altitud media de sus áreas potenciales. Habrá una pérdida en su distribución potencial: entre 84 y $98 \%$ para los pastos de alta montaña; 79 y $97 \%$ para los matorrales subalpinos y alpinos, y 90 y $68 \%$ para los bosques subalpinos bajo los diferentes escenarios climáticos (escenarios A2 y B2, respectivamente).

En el ámbito nacional, destaca el trabajo de Villers et al. (1998) donde evaluaron el impacto del cambio climático con dos modelos de circulación general (MCG) sobre áreas naturales protegidas (ANP). Según los resultados de 33 ANP analizadas, 24 se verían afectadas por el cambio de su vegetación original, lo cual provocaría efectos negativos en la flora y fauna, o habría migración hacia ambientes más propicios; así mismo, 13\% de los bosques templado- fríos y cálidos del país desaparecerían; al contrario, los bosques tropicales espinosos secos y muy secos con temperaturas mayores a $24^{\circ} \mathrm{C}$ aumentarían. Por su parte, Monterroso et al. (2010) emplearon los modelos MCG CCM, GFDL, HADLEY y ECHAM para Abies religiosa (Kunth) Schltdl. et Cham. y Pinus pseudostrobus Lindl. en el Parque Nacional Nevado de Toluca. La investigación reveló un incremento en el área de distribución y una altitud de $100 \mathrm{~m}$ hacia el 2020 y de $400 \mathrm{~m}$ hacia el 2050 para A. religiosa, mientras que para $P$. pseudostrobus fue de $100 \mathrm{~m}$ hacia 2020 y de 300 m hacia 2050.

Gómez et al. (2009b) generaron modelos de cambio climático a escala regional al 2030 y 2050 para especies forestales como Pinus patula Schltdl. et Cham. y Pinus pseudostrobus. El primer taxon tuvo una destacada presencia en las Sierra Madre Oriental y Occidental, Sierra Volcánica Transversal y Sierra Madre del Sur, con una superficie apta de $0.4 \%$ en todo el territorio nacional; el segundo, se ubicó en la Sierra Madre Occidental con una distribución apta de $1.7 \%$ en el país.

Pinus pseudostrobus es una de las especies más utilizadas en proyectos de reforestación en México y se desarrolla principalmente en las entidades del centro, como Morelos, Puebla, Hidalgo, Estado de México y Distrito Federal, y en los sureños de Oaxaca, Chiapas y Guerrero; mientras que al norte su distribución es escasa (Viveros et al., 2006). Se localiza en comunidades vegetales de bosque de coniferas y bosque de pino-encino (Stead, 1983). Es productora de resina, pero su madera se destina al aserrío, triplay, chapa, cajas de empaque, molduras, así como a la industria de la predicting the distribution of Pinus kesiya Royle ex Gordon and P. merkusii Jungh \& de Vriese for 2050, under the HADCM3 and CCCMA general circulation models; it is expected that both species are benefited by climate change as there are new places with ideal conditions for their establishment at higher altitudes. Pérez et al. (2011) studied the subalpine and alpine habitats consisting of $P$. uncinata Miller forests, shrubs, and pastures; results predict an increase of average altitude of the potential areas of these habitats. There will be a loss in their potential distribution: between 84 and 98\% for the high mountain pastures; between 79 and $97 \%$ for subalpine and alpine shrubs; and between 90 and $68 \%$ for subalpine forests under the different climate scenarios (A2 and $\mathrm{B} 2$, respectively).

In the national sphere, the work of Villers et al. (1998), in which they evaluated the impact of climate change with two models of general circulation (MCG) on national protected areas (ANP), stands out. According to the results of the 33 ANPs analyzed, 24 would be affected by the change in their original vegetation, which would have negative effects on the flora and fauna, or migration towards more suitable environments. Moreover, $13 \%$ of both cold and warm temperate forests would disappear. In contrast, the dry and very dry spiny tropical forests, with temperatures over $24^{\circ} \mathrm{C}$, would increase in number. Monterroso et al. (2010) used the MCG CCM, GFDL, HADLEY and ECHAM models for Abies religiosa (Kunth) Schltdll. et Cham., and Pinus pseudostrobus Lindl. in the Nevado de Toluca National Park. The study revealed an expansion in the distribution area, as well as an altitude of $100 \mathrm{~m}$ for 2020, and of $400 \mathrm{~m}$ for 2050 for A. religiosa, whereas for P. pseudostrobus it was of $100 \mathrm{~m}$ for 2020, and of $300 \mathrm{~m}$ for 2050 .

Gómez et al. (2009b) generated climate change models at a regional level for 2030 and 2050, for forest species such as Pinus patula Schltall. et Cham. and Pinus pseudotrobus. The former had a significant presence in the Sierra Madre Oriental, Sierra Madre Occidental, Eje Neovolcánico Transversal and Sierra Madre del Sur, with a suitable surface of $0.4 \%$ in the entire national territory. The latter was located in the Sierra Madre Occidental, with a suitable distribution of $1.7 \%$ in the whole country.

Pinus pseudostrobus is one of the mostly used species in reforestation projects in Mexico, and mainly grows in the Central states, such as Morelos, Puebla, Hidalgo, Estado de México, and Distrito Federal, as well as in the southern states of Oaxaca, Chiapas, and Guerrero; in contrast, it is scarcely present in the north (Viveros et. al., 2006). It is located in vegetable communities of coniferous forests and pine-oak forests (Stead, 1983). This species is a resin producer, but its timber is used for sawmilling, plywood, sheets, packaging, moldings, as well as for construction and manufacturing windows, fine furniture, hand crafts, joinery and paper pulp. It is highly appreciated for commercial plantations, given its ornamental qualities, which is why it is used in sports fields and parks (Gómez, 2009a). 
construcción, fabricación de ventanas, muebles finos, artesanías, ebanistería y pulpa de papel. Es valorada para plantaciones comerciales, así como por sus cualidades ornamentales, por lo que se le utiliza en campos deportivos y parques (Gómez, 2009a).

Pinus patula es uno de los pinos nativos de Centroamérica; en otros países ofrece grandes ventajas para plantaciones industriales en zonas tropicales y subtropicales de Sudáfrica y América del Sur. En México se distribuye de manera natural sobre formaciones montañosas de la Sierra Madre Oriental, Eje Neovolcánico y Sierra Madre de Oaxaca, en los estados de Nuevo León, Tamaulipas, Hidalgo, Puebla, Veracruz, Oaxaca, Querétaro, Tlaxcala y Distrito Federal; no obstante, las poblaciones con óptimo desarrollo se ubican en Hidalgo, Puebla y Veracruz, y las grandes plantaciones comerciales en el Estado de México, Puebla, Michoacán y Distrito Federal (Conafor y Pronare, 2006). Su madera es de menor fortaleza y densidad que la de otras coníferas; sin embargo, es adecuada para la industria de la construcción (Gillespie, 1992).

El Estado de México posee una superficie de 172700.655 ha de bosques de pino (INEGI, 2010). Según la Protectora de Bosques (2006), 80\% de los pinos tienen valor económico debido a su potencial de aprovechamiento con fines maderables; algunos de ellos son P. douglassiana Martínez, P. michoacana Martínez, P. montezumae Lamb., P.teocote Schltdl. y P. pseudostrobus; así, este último es significativo en la producción de madera y resina industrial para el Estado de México, al igual que $P$. patula para la restauración de suelo, plantaciones industriales y madera de uso diverso. En la actualidad ambas especies tienen relevancia ecológica, económica y social para la entidad, en virtud de que presentan riesgos ante el cambio climático. Este fenómeno traería pérdidas en la producción forestal entre los productores forestales, por ello la importancia de conocer la distribución potencial de los pinos bajo estudio, con escenarios de climáticos, para que sirva de apoyo para los tomadores de decisiones en las medidas de mitigación y adaptación ante el fenómeno cambiante.

El objetivo del estudio es comparar la distribución potencial actual de P. patula y P. pseudostrobus bajo escenarios de cambio climático con modelos de circulación general de la atmósfera (MCG) y con Ensambles de los MCG.

\section{MATERIALES Y MÉTODOS}

Área de estudio

El Estado de México se sitúa entre las coordenadas $18^{\circ} 21^{\prime}$ '29" y $20^{\circ} 17^{\prime} 20^{\prime \prime}$ latitud norte, y $98^{\circ} 35^{\prime} 50^{\prime \prime}$ y $100^{\circ} 36^{\prime} 34^{\prime \prime}$ longitud oeste (Figura 1) y tiene una extensión territorial de 22499.95 km² (INEGl, 2007).

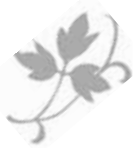

Pinus patula is one of the native pines of Central America; in other countries, it is highly useful for industrial plantations in tropical and subtropical zones of South Africa and South America. In Mexico, it is naturally distributed in the mountain formations of the Sierra Madre Oriental, Eje Neovolcánico and Sierra Madre de Oaxaca, in the states of Nuevo León, Tamaulipas, Hidalgo, Puebla, Veracruz, Oaxaca, Querétaro, Tlaxcala and Distrito Federal. However, populations with optimal development are located in Hidalgo, Puebla and Veracruz, and large commercial plantations are found in Estado de México, Puebla, Michoacán and Distrito Federal (Conafor and Pronare, 2006). Its wood is less strong and dense than that of other conifers; yet, it is quite useful in construction (Gillespie, 1992).

In Estado de México 172700.655 ha are covered by pine forests (INEGI, 2010). According to the Protectora de Bosques (2006), 80\% of pines has financial value due to their potential exploitation for timber products; some of these species are P. douglassiana Martínez, P. michoacana Martínez, P. montezumae Lamb., P. teocote Schltdl. and $P$. pseudostrobus. The latter is quite significantly used for production of timber and industrial resin in Estado de México, as is $P$. patula for soil restoration, industrial plantations and production of timber for diverse uses. Nowadays, both species are ecologically, economically and socially relevant for the state, but they are at risk under climate change. This phenomenon would cause losses in forest production among forest producers, which is why it is important to learn the potential distribution of the pines studied here, under different climate change scenarios, so that the resulting information can be helpful for decision makers in terms of mitigation and adaptation to the changes to come.

The purpose of this study was to compare the current potential distribution of $P$. patula and $P$. pseudostrobus under climate change scenarios with general circulation models of the atmosphere (MCG) and ensemble of the MCGs.

\section{MATERIALS AND METHODS}

\section{Study area}

Estado de Mexico is situated between $18^{\circ} 21^{\prime} 29^{\prime \prime}$ and $20^{\circ} 17^{\prime} 20$ " North, and between $98^{\circ} 35^{\prime} 50^{\prime \prime}$ and 100 36' 34" West (Figure 1), and has $22499.95 \mathrm{~km}^{2}$ (INEGI, 2007).

The most regular soils in the state are Feozem and Andosol (45\%); Cambisols, Luvisols, Regosols and Vertisols (37\%); Fluvisols, Molic Gleysol, Eutric Histosol, Ranker and Rendzina (5.6\%); and others (12.4\%). Predominant textures are medium and fine $185 \%$ of the whole land) (INEGI, 2007) and altitude ranges from $200 \mathrm{~m}$ in the south of the state to $5500 \mathrm{~m}$ in the east.

Estado de Mexico is divided into two physiographic provinces: the Eje Neovolcánico and the Sierra Madre del Sur, and 


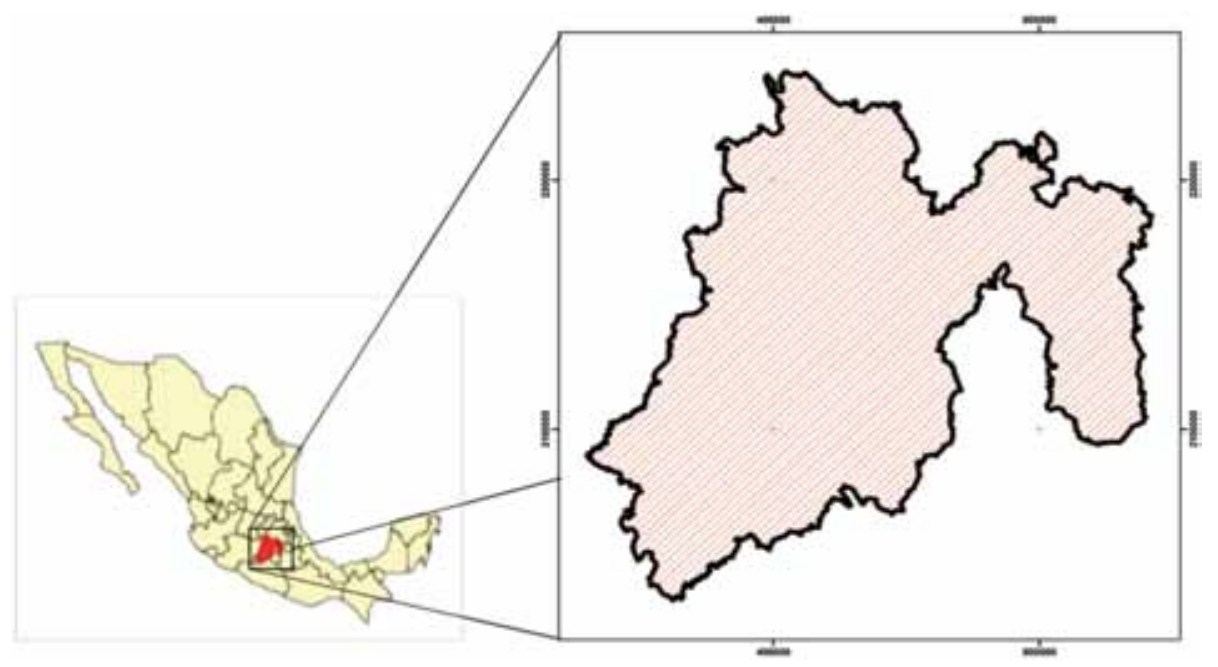

Figura 1. Localización del área de estudio. Figure 1. Location of the study area.

Las unidades edáficas de mayor cobertura en el estado son Feozem y Andosol con 45\%; Cambisoles, Luvisoles, Regosoles y Vertisoles representan 37\%; Fluvisoles, Gleysol Mólico, Histosol Eutrico, Ranker y Rendzina, $5.6 \%$, y otros, $12.4 \%$. Las clases texturales predominantes son media y fina (85\% de la superficie) (INEGI, 2007), y el intervalo altitudinal abarca desde los $200 \mathrm{~m}$ en la parte sur hasta los $5500 \mathrm{~m}$ en la parte este.

El Estado de México se divide en dos provincias fisiográficas: el Eje Neovolcánico y la Sierra Madre del Sur, y sus elevaciones principales son el volcán Popocatépetl (5 500 msnm), volcán Iztaccíhuatl (5 200), Nevado de Toluca (volcán Xinantécatl) (4,680), Cerro el Mirador (4, 120) y Cerro Telapón (4060).

Los climas más importantes son los templados: subhúmedo (CW), semifrío húmedo $\left(C o\left(w_{2}\right)\right.$, subhúmedo $\left.(A) C w\right)$; el cálido subhúmedo (Aw); el semiárido templado (BSlk) y el frío (E(T)CHw) (INEGI, 2007). La entidad está conformada por las regiones hidrológicas Lerma-Santiago, con una superficie que ocupa $23.75 \%$ de su territorio; Balsas, con una de $41.86 \%$, y Pánuco, con una de $34.39 \%$ (INEGl, 2007).

El estado cuenta con 609000 ha forestales, de las cuales 560000 corresponden a bosque de clima templado y frío (282 802 ha son bosques de coniferas). Los bosques de coníferas, latifoliadas y mixtos están representados por oyamel (Abies religiosa), ocote blanco (Pinus montezumae), pino chino (Pinus leiophylla Schiede ex Schltall. et Cham), encino quebracho (Quercus rugosa Née) y encino laurelillo (Quercus mexicana Bonpl.) (INEGI, 2008).

\section{Selección de especies}

Se estudiaron dos especies forestales de importancia económica y de restauración para el Estado de México: Pinus patula, cuyos their main elevations are Popocatépetl volcano (5 500 masl), Iztaccíhuatl volcano (5200 mas)), Nevado de Toluca (Xinantécatl volcano) (4680 masl), Cerro El Mirador (4 120 masl) and Cerro Telapón (4060).

The most important climates in the study area are temperate: sub-humid (CW), semi-cold humid (Co(w $)$, sub-humid (A) CW); warm sub-humid (Aw); temperate semi-arid (BSTk); and cold (E(T) $\mathrm{CH}$ w) (INEGI, 2007). The state is constituted by the following hydrologic regions: Lerma-Santiago, occupying $23.75 \%$ of the territory; Balsas, 41.86\%; and Pánuco, 34.39\% (INEGl, 2007).

The state has 609000 ha of forest, 560000 of which are temperate and cold forests (282 802 ha correspond to soffwood forests). Coniferous, broadleaved and mixed forests are represented by species such as sacred fir (Abies religiosa), Montezuma pine (Pinus montezumae), Chinese pine (Pinus leiophylla Schiede ex Schltdl. et Cham.), quebracho (Quercus rugosa Née), and laurelillo (Quercus mexicana Bonpl.). (INEGI, 2008).

\section{Species selection}

Two forest species of economic and restorative importance for Estado de Mexico were studied: Pinus patula, commonly known as patula pine, ocote, weeping pine, sad pine, red pine, Chinese pine, among other names; and Pinus pseudostrobus Lindl., also known as pseudostrobus pine, ortiguillo, and altamirano. Their agro-ecological requirements were obtained from the Sistema de Información de Reforestación (SIRE) (Conabio-Pronare, 2006) and Eguiluz (1978) and are shown in Table 1.

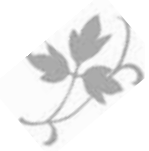


nombres comunes son pino patula, ocote, pino llorón, pino triste, pino colorado, pino chino, entre otros, y Pinus pseudostrobus Lindl. con los nombres de pino pseudostrobus, pino ortiguillo y altamirano. Sus requerimientos agroecológicos se obtuvieron del Sistema de Información de Reforestación (SIRE) (Conabio-Pronare, 2006) y de Eguiluz (1978) y se presentan en el Cuadro 1.
Digital cartography to assess the current potential distribution

Digital cartography to determine the suitability of the land according to the requirements of the forest species was produced, and in which altitude, climate (total annual rainfall and annual average

Cuadro 1. Requerimientos agroecológicos de especies forestales evaluadas.

Table 1. Agro-ecological requirements of the assessed forest species.

\begin{tabular}{|c|c|c|c|c|c|c|}
\hline $\begin{array}{l}\text { Variable / } \\
\text { Especie }\end{array}$ & Altitud (msnm) & $\begin{array}{c}\text { Precipitación } \\
\text { total anual } \\
(\mathrm{mm})\end{array}$ & $\begin{array}{c}\text { Temperatura } \\
\text { media anual } \\
\left({ }^{\circ} \mathrm{C}\right)\end{array}$ & $\begin{array}{l}\mathrm{pH} \text { del suelo } \\
\text { (escala) }\end{array}$ & $\begin{array}{c}\text { Textura del suelo } \\
\text { (clase) }\end{array}$ & $\begin{array}{c}\text { Profundidad del } \\
\text { suelo }(\mathrm{cm})\end{array}$ \\
\hline P. patula Schltdl. et Cham. & $1800-2800$ & $800-2000$ & $10-20$ & $3.8-6.6$ & gruesa - media & $60-120$ \\
\hline P. pseudostrobus Lindl. & $1800-3000$ & $800-1500$ & $09-20$ & $5.0-6.5$ & gruesa - media & $95-120$ \\
\hline
\end{tabular}

Cartografía digital para la evaluación de la distribución potencial actual

Se obtuvo la cartografía digital para determinar la aptitud del terreno en función de los requerimientos, los cuales fueron de tipo altitudinal, climática (precipitación total y temperatura media anuales) y edáfica (pH del suelo, textura y profundidad) (Figura 2).

La precipitación total anual y la temperatura media anual se crearon a partir de la base de datos del Instituto Nacional de Investigaciones Forestales, Agrícolas y Forestales (INFAP), actualizada al 2003. La primera tiene un margen de error entre 27 y $33 \mathrm{~mm}$, y la segunda, uno de 0.5 a $0.8^{\circ} \mathrm{C}$ (Díaz, 2007). $\mathrm{El} \mathrm{pH}$, la profundidad y la textura del suelo se generaron de la interpolación de los pozos pedológicos de cartas edafológicas del INEGl escala 1:50 000 y 1:250 000, y de una base de datos del INIFAP elaborada para áreas agrícolas del estado, con datos recogidos en un retícula cada 1,000 m. Los datos se interpolaron con el método de inversa a la distancia al cuadrado $\left(\mathbb{D W}_{2}\right)$ con los 10 puntos vecinos más cercanos. La cobertura de altitud se obtuvo a partir del modelo digital de elevación (MED) de la página electrónic http://mapserver.inegi.org.mx/DescargaMDEWeb/ con una resolución de $50 \mathrm{~m}$. La cartografía digital fue procesada en el soffware ARCGIS 9.3 $3^{\text {TM }}$ con la proyección UTM y datum WGS84.

\section{Cartografía digital para la evaluación de la distribución potencial con cambio climático}

Los estudios de cambio climático utilizan distintos modelos de clima y escenarios de emisiones con el propósito de expresar un nivel de incertidumbre menor, y se adaptan a fluctuaciones de emisiones de GEl, modificaciones tecnológicas, población, grado de desarrollo económico, entre otros. Los escenarios representan una alternativa del comportamiento del clima futuro y existen dos tipos: A, que describe un mundo con alto crecimiento económico, y temperature), and soil (soil pH, texture, and depth) were included (Figure 2).

Total annual rainfall and annual average temperature were determined starting from the database of the Instituto Nacional de Investigaciones Forestales, Agrícolas y Forestales (INFAP), last updated in 2003. It has a margin error that ranges from 27 to $33 \mathrm{~mm}$ and from 0.5 to $0.8^{\circ} \mathrm{C}$ (Díaz, 2007). Soil pH, depth and texture were defined by interpolating pedological pits from edaphological charts made by INEGl in two scales ( 1:50 000 and 1:250 000), and a database elaborated by INIFAP of the agriculture areas of the state, with data obtained from grids every 1,000 m. Data were interpolated by using the inverse distance squared weighting $\left(\mathbb{D W} W_{2}\right)$, with the 10 closest neighboring points. Altitude was obtained from the digital elevation model (MED) of the website http:// mapserver.inegi.org.mx/DescargaMDEWeb/, with a resolution of $50 \mathrm{~m}$. The digital cartography was processed using the ARCGIS 9.3 ${ }^{T M}$ software, with UTM projection and WGS84 datum.

\section{Digital cartography for evaluating the potential distribution under climate change}

Climate change studies use different climate models and emission scenarios in order to express a lower uncertainty level, and adapt to GHG emission fluctuations, technological modifications, population, and level of economic development, among other things. Such scenarios represent an alternative of the behavior of the future climate, and are classified into two types: $A$, which describes a world with high economic growth; and $B$, which implies a moderate growth. $\mathrm{Al}$ and $\mathrm{Bl}$ scenarios consider that there will be a globalization and that the development of economies will converge; whereas A2 and B2 scenarios consider local development (Conde et al., 2008).

The MCGs of the atmosphere used for generating the climate change scenarios were GFDL 2.0, from the United States, and 
B, con un crecimiento moderado. Los escenarios Al y Bl suponen que habrá una globalización y las economías convergerán en su desarrollo, mientras que en los A2 y B2 se considera un desarrollo a nivel local (Conde et al., 2008).

Los MCG de la atmósfera empleados a fin de generar los escenarios de cambio climático fueron el GFDL 20 de Estados Unidos y HAD GEM (versión 1) de lnglaterra, con una resolución espacial de $10 \times 10 \mathrm{~km}$ y escenarios A2 para los años 2030 y 2050 (Conde et al., 2008). También se utilizaron escenarios regionales de cambio climático por ensamble, resultados del promedio de 10 MCG y de escenario de emisiones A2. Los MCG empleados en la generación de Ensamble Regional fueron: mpi _ echam5, miub _ echo _ g, csiro _ mk3 _ O, csiro _ mk3 _ 5, cccma cgcm3 _ 1, giss _ model_e_r, ncar_ccsm3_0, miroc3_ 2 h hires, mri_cgcm2 3 $2^{a}$ y u $\bar{k}$ mo hadcm3, y la resolución espacial fue de 50 x $50 \mathrm{~km}$. Este ensamble permite conocer el intervalo de condiciones futuras del clima más probable para el país (Magaña, 2010). Los datos mensuales de temperatura y precipitación se interpolaron con el IDW ${ }_{2}$ con ocho puntos más cercanos en $\operatorname{Arc~Map~}^{\text {TM }}$ 9.3. Se alcanzaron coberturas mensuales por variable, escenario, periodo y modelo, y se les aplicaron operaciones algebraicas para generar la precipitación total anual y la temperatura media anual.

Reglas de restricción

Se emplearon reglas de restricción bajo la definición de "no aptos" a los espacios urbanos, cuerpos de agua, zonas agrícolas y suelos Litosoles. Las tres primeras se obtuvieron de la Carta Uso de Suelo y Vegetación de la Serie III (INEGI, 2005) escala 1:250 000, y la última, de la Carta Edafológica digitalizada por INIFAP y Conabio (1995), escalas 1: 250000.

\section{Obtención de la cartografía de aptitud forestal}

Se realizó una reclasificación de los valores de las coberturas digitales de cada variable, según los requerimientos agroecológicos de cada especie. Se usaron dos categorías: Apto (1) y No Apto (0), y después se aplicaron las reglas de restricción. Las variables climáticas, temperatura media anual y precipitación total anual; las del suelo, pH, textura y profundidad, así como la altitud, fueron procesadas para Arc Map ${ }^{T M}$ mediante el método de lógica booleana.

Para la evaluación de la aptitud con escenarios de CC, el procedimiento fue similar, excepto porque se sustituyeron las variables climáticas actuales por las estimadas en cada escenario y periodo de los MCG de la atmósfera GFDL 2.0 y HADGEM, y los de ensamble de MCG (Figura 2).

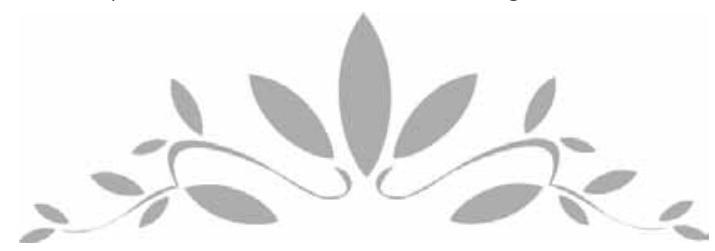

HADGEM (version 1) from England, with a spatial resolution of 10 $\times 10 \mathrm{~km}$, and A2 scenarios for the years 2030 and 2050 /Conde et al., 2008). A regional ensemble of climate change scenarios was used too, which resulted from the average of 10 MCGs and from the A2 emission scenario. The MCGs used for generating the Regional Ensemble were mpi_echam5, miub_echo _g, csiro _mk3 _ O, csiro _ mk3 _ 5, cccma cgcm3 _ 1, giss _ model _ e $r$, ncar _ ccsm3_0, miroc3_2 hires, mri cgcm2 3 2 $2^{a}$ y ukmo hadcm3, and the spatial resolution was of $50 \times 50 \mathrm{~km}$. This ensemble helps to know the likeliest range of future climate conditions for the country (Magaña, 2010). Monthly temperature and rainfall data were interpolated with the $\mathbb{D W W}_{2}$ with eight closest points, using Arc Map $^{\text {TM }}$ 9.3. A monthly coverage per variable, scenario, period, and model were obtained and algebraic expressions were used to calculate total annual rainfall and average annual temperature.

\section{Restriction rules}

Restriction rules for urban spaces, water bodies, agriculture areas and litosol soils were used, all of which were defined as "unsuitable". The location of the first three was obtained from the Soils Use and Vegetation Map Series III (INEGI, 2005) (1:250 000 scale), and the data for the last from the Soil Map, digitalized by INFAP and Conabio (1995) (1:250 000 scale).

\section{Obtaining the forest suitability cartography}

The digital cover values for each variable, according to the agro-ecological requirements of each species were reclassified. Two categories were considered: suitable (1) and unsuitable (O), and then the restriction rules were applied. Climate variables (average annual temperature and total annual rainfall), soil variables (pH, texture and depth), as well as altitude variables were processed for their input in $\operatorname{Arc~Map~}^{\text {TM }}$ by the Boolean logic method.

For evaluating the suitability under CC scenarios, the process was quite similar, except that the current climate variables were substituted by those estimated in each scenario, period of the MCG of the atmosphere (GFDL 2.0 and HADGEM) and ensemble of the MCGs (Figure 2).

\section{RESULTS AND DISCUSSION}

Pinus patula shows different levels of suitability in Estado de México: high suitability in 18104.73 ha (which represents $64.11 \%$ of the coniferous forest surface in the state), and medium suitability in 27359.61 (which corresponds to 96.66\%) (Table 2).

The current highly suitable surface for $P$. patula is barely found in the south of the state, in a strip that runs from East to West. At the east, it is found in limited areas: in the lower part of the western slopes of Popocatépetl and lztaccihuatl volcanoes, in pine, pine-oak, oak-pine and oak forests, as well as in secondary vegetation 


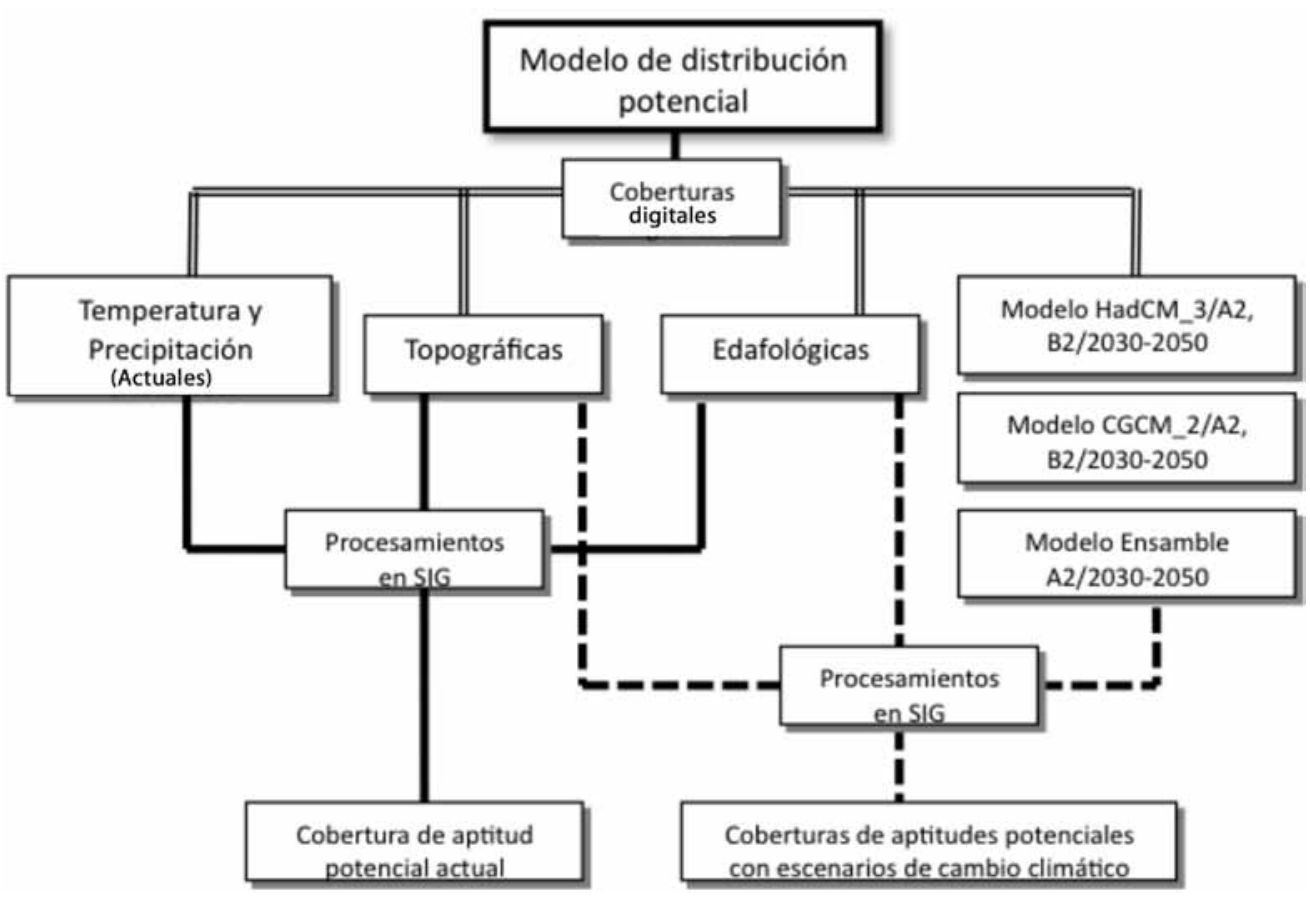

Figura 2. Procedimiento del modelo de distribución potencial.

Figure 2. Procedure of the potential distribution model.

\section{RESULTADOS Y DISCUSIÓN}

En el Estado de México Pinus patula presenta diferentes una aptitud alta de 181304.73 ha lequivalente a $64.11 \%$ de la superficie forestal de coníferas de la entidad), y una media de 273359.61 ha (equivalente a 96.66\%) (Cuadro 2).

Cuadro 2. Niveles de aptitud del terreno actual y con escenarios de cambio climático para Pinus patula Schltdl. et Cham.

Table 2. Suitability levels of the current surface and under climate change scenarios for Pinus patula Schltdl. et Cham.

\begin{tabular}{lcc}
\hline Aptitud actual & Superficie apta (ha) & $\%^{*}$ \\
\hline Alta & 181304.73 & 64.11 \\
Media & 273359.61 & 96.66 \\
\hline
\end{tabular}

* Porcentaje con respecto a la superficie forestal de coníferas.

* Per cent in regard to the softwood forest area.

La aptitud actual con nivel alto del P. patula escasamente existe en la zona sur de la entidad, en una frania que va de oriente a occidente. En el oriente se halla en áreas reducidas: en la parte baja de la vertiente occidental de los volcanes Popocatépetl e lztaccíhuatl en bosque de pino, pino-encino, encino-pino, encino, vegetación secundaria de encino y agricultura de temporal. En la Sierra Monte Alto y en la Sierra de Las Cruces está poco distribuido en áreas de bosques de encino, pino y agricultura de temporal. En la vertiente sur y suroeste del Nevado de Toluca se localiza en bosque de pino, pino-encino y agricultura de temporal; en la Sierra Occidental, en bosque de pino-encino y agricultura de oak forests, and rain-fed agriculture zones; in the Sierra Madre Occidental, in pine-oak forests and rain-fed agriculture zones; and in the northwest, in oak and oak-pine forests (Figure 3).

The extension of medium suitability is broader than that of higher suitability. In the eastern part of the state, high suitability is geographically widely spread and is displayed around Popocatépetl and Iztaccíhuatl volcanoes in pine forests. In these areas, the development of this species would be limited by altitude and temperature, according to the result of the modeling process of GIS. In the Sierra Monte Alto, Sierra de Las Cruces, La Marquesa and the southern part of the latter, the medium suitable area is located in fir, pine, oak-pine and oak forests, and in rain-fed agriculture areas. In Nevado de Toluca, it is mainly found in pine forests, secondary pine-oak forests, and rain-fed agriculture areas. In Valle de Bravo, it is found in pine and pine-oak forests, and rain-fed agriculture areas. In the Sierra Occidental, it is present in fir and pine-oak forests, and secondary vegetation fir forests, as well as in rain-fed agriculture lands. In the northwestern and northern areas, it is found in oak-pine and oak forests, and rain-fed agriculture. The main limitations for the development of $P$. patula in these places are altitude, soil depth, and average temperature.

The suitability for $P$. patula under A2 climate change scenario shows contrasting territories. For 2030, the suitable extension using the GFDL 20 model shows a wider surface than when using the HADGEM model, with 5.9\% ( 10704 ha); however, results are absolutely divergent with those of the ensemble of MCGs, since they represent a difference of $46.84 \%$ (which amounts to 84927 ha) in contrast with 


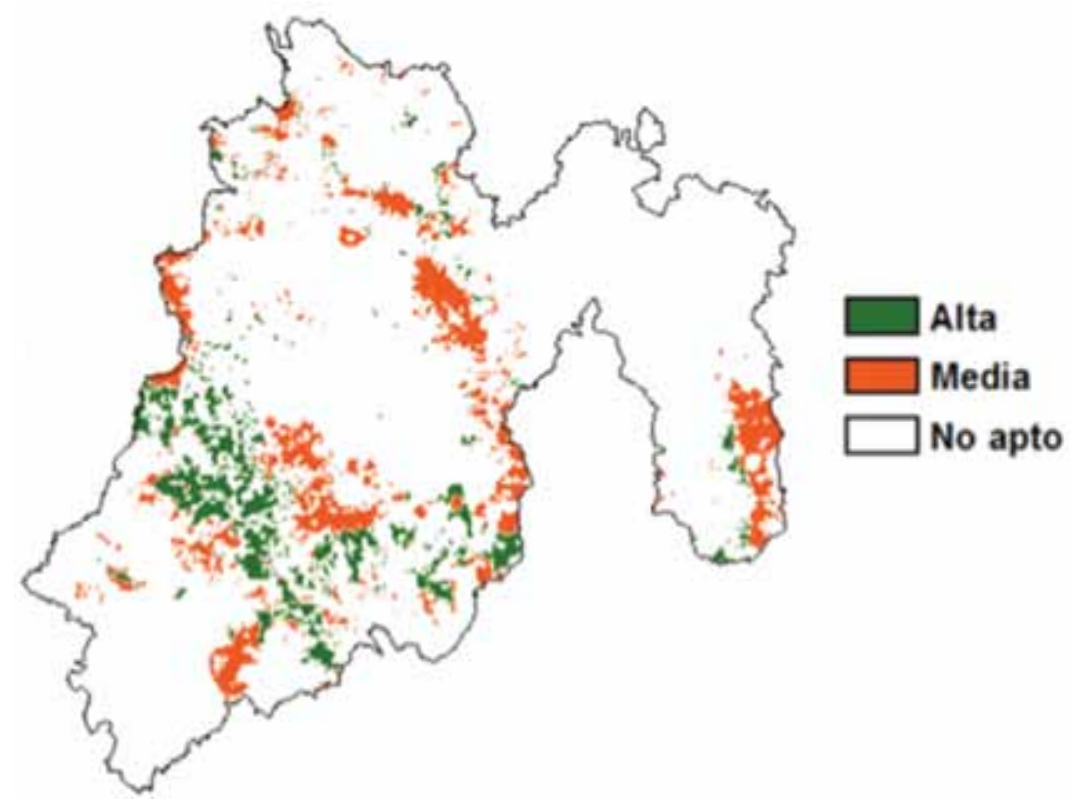

Figura 3. Distribución potencial actual del P. pseudostrobus Lindl.

Figure 3. Current potential distribution of Pinus pseudostrobus Lindl.

temporal, y en la parte noroccidental, en bosque de encino y encino-pino (Figura 3).

La extensión de la aptitud media es más amplia que la alta. En la parte este de la entidad, geográficamente tiene suficiente amplitud y está repartida alrededor de los volcanes Popocatépetl e lztaccíhuatl en bosques de pino. En estas áreas el desarrollo de la especie tendría limitantes por altitud y temperatura, de acuerdo al resultado del proceso del modelado en el SIG. En la Sierra Monte Alto, Sierra de Las Cruces, La Marquesa y al sur de esta última, crece en bosques de oyamel, pino, encino-pino, encino y agricultura de temporal. En el Nevado de Toluca se ubica principalmente en bosque de pino, bosques secundarios de pino-encino y agricultura de temporal; en Valle de Bravo, en bosques de pino, pino-encino y agricultura de temporal; en la Sierra Occidental, en bosque de oyamel, pino-encino y vegetación secundaria de oyamel y agricultura de temporal, y en la porción noroccidental y norte, en bosque de encino-pino, encino y agricultura de temporal. Las principales limitantes para el desarrollo del P. patula en estas áreas son la altitud, profundidad del suelo y temperatura media.

La aptitud de P. patula con escenarios de cambio climático del tipo A2 tiene superficies contrastantes. Para el periodo 2030, la extensión de aptitud con el modelo GFDL 2.0 presenta mayor superficie que el HADGEM con 5.9\% (10704 ha); sin embargo, los resultados son en absoluto discrepantes con el Ensamble de MCG, ya que las diferencias son del orden de 46.84\% (equivalente a 84927 ha) con respecto al GFDL. La misma situación ocurre con la aptitud media entre GFDL 2.0 y HADGEM, donde la divergencia es de 1.35\% (3686 ha), y the GFDL model. The same happens with the medium suitability between the GFDL 2.0 and HADGEM models, where there is a difference of 1.35\% (3686 ha) and between the GFDL 2.0 model and the ensemble of MCGs, which is of $9.60 \%$ (26244 ha) (Table 3).

For 2050, the highly suitable surface is wider with the GFDL 2.0 model than with the HADGEM model by $11.30 \%$ (20 482 ha). In contrast, results are different when using the ensemble of MCGs: 4.72\% (62 $954 \mathrm{ha}$ ) more than the highly suitable surface expressed in the GFDL 2.0 model. Something similar happens with medium suitability; the difference between the GFDL 2.0 and HADGEM models is $3.71 \%$ ( $10145 \mathrm{ha}$ ), and between the GFDL 2.0 and the ensemble of MCGs is $2.43 \%$ (6 647 ha) (Figure 4).

Pinus pseudostrobus has a GIS significant suitable area in the state: high suitability is 93425.40 ha $133.04 \%$ of the coniferous forest surface in the state), and the medium suitability land is 249051.51 ha (88.07\%) (Table 4).

The current highly suitable territory for $P$. pseudostrobus is scarcely distributed in a strip in the central part of the state that runs from East to West. In the east, it is dispersed in small regions located at the lower part, in rain-fed agriculture places to the middle high part, in secondary pine-oak and pine forests. In the Sierra Monte Alto and Sierra de Las Cruces, it is located in oak, pine and fir forests, and in rain-fed agriculture lands. In the south and southeast slope of Nevado de Toluca, it is located in pine, pine-oak and fir forests, and in rain-fed agriculture areas. In the Sierra Occidental, it is found in pine-oak and fir forests, in secondary vegetation fir forests 
Cuadro 3. Superficie de aptitud de Pinus patula Schltdl. et Cham. con escenarios de cambio climático tipo A2 (en hectáreas). Table 3. Suitable surface for P. patula Schltdl. et Cham. under A2 climate change scenarios (expressed in hectares).

\begin{tabular}{ccccc}
\hline Periodo & Aptitud & GFDL 2.0 & HADGEM & Ensamble de MCG $\infty$ \\
\hline \multirow{2}{*}{2030} & Alta & 86131 & 75426 & 171057 \\
& $\%^{*}$ & 47.51 & 41.60 & 94.35 \\
& Media & 231962 & 228277 & 258206 \\
& $\%^{*}$ & 84.86 & 83.51 & 94.46 \\
& Alta & 97997 & 77515 & 160951 \\
& $\%{ }^{*}$ & 54.05 & 42.75 & 88.77 \\
& Media & 232660 & 222514 & 239306 \\
& $\%^{*}$ & 85.11 & 81.40 & 87.54 \\
\hline
\end{tabular}

$\infty$ Modelos de circulación general de la atmósfera; ${ }^{*}$ Porcentaje con la superficie actual.

$\infty$ Atmospheric general circulation models ${ }^{*}$ Per cent of the present area

entre GFDL 2.0 y Ensambles de MCG, que es de $9.60 \%$ (26244 ha) (Cuadro 3).

Para el periodo 2050, la superficie de aptitud alta con el modelo GFDL 2.0 muestra mayor superficie que el HADGEM: 11.30\% (20 482 ha). Al contrario, los resultados son diferentes con el Ensamble de MCG, pues estos son mayores: $4.72 \%$ lequivalente 62954 ha) más, respecto al GFDL 2.0. La situación es similar con la aptitud media; la discrepancia entre GFDL 2.0 y HADGEM es de $3.71 \%$ ( $10145 \mathrm{ha}$ ), y la de GFDL 2.0 con el Ensambles de MCG, de 2.43\% (6 647 ha) (Figura 4). and in rain-fed agriculture sites. And in the northwestern part of the state, it is located in oak forests and in rain-fed agriculture areas (Figure 5).

The distribution of the medium suitable area is larger and wider than that of high suitability. In the eastern part of the state, it is located in pine and oak forests, and, in a smaller proportion, in rain-fed agriculture lands. These spaces have limitations of soil depth and altitude, and some others are also limited by the $\mathrm{pH}$. In the Sierra Monte Alto, Sierra de Las Cruces and La Marquesa (southern area), it is found in fir, pine, oak-pine, cloud and oak forests, and in rain-fed agriculture areas. In the Nevado de Toluca,

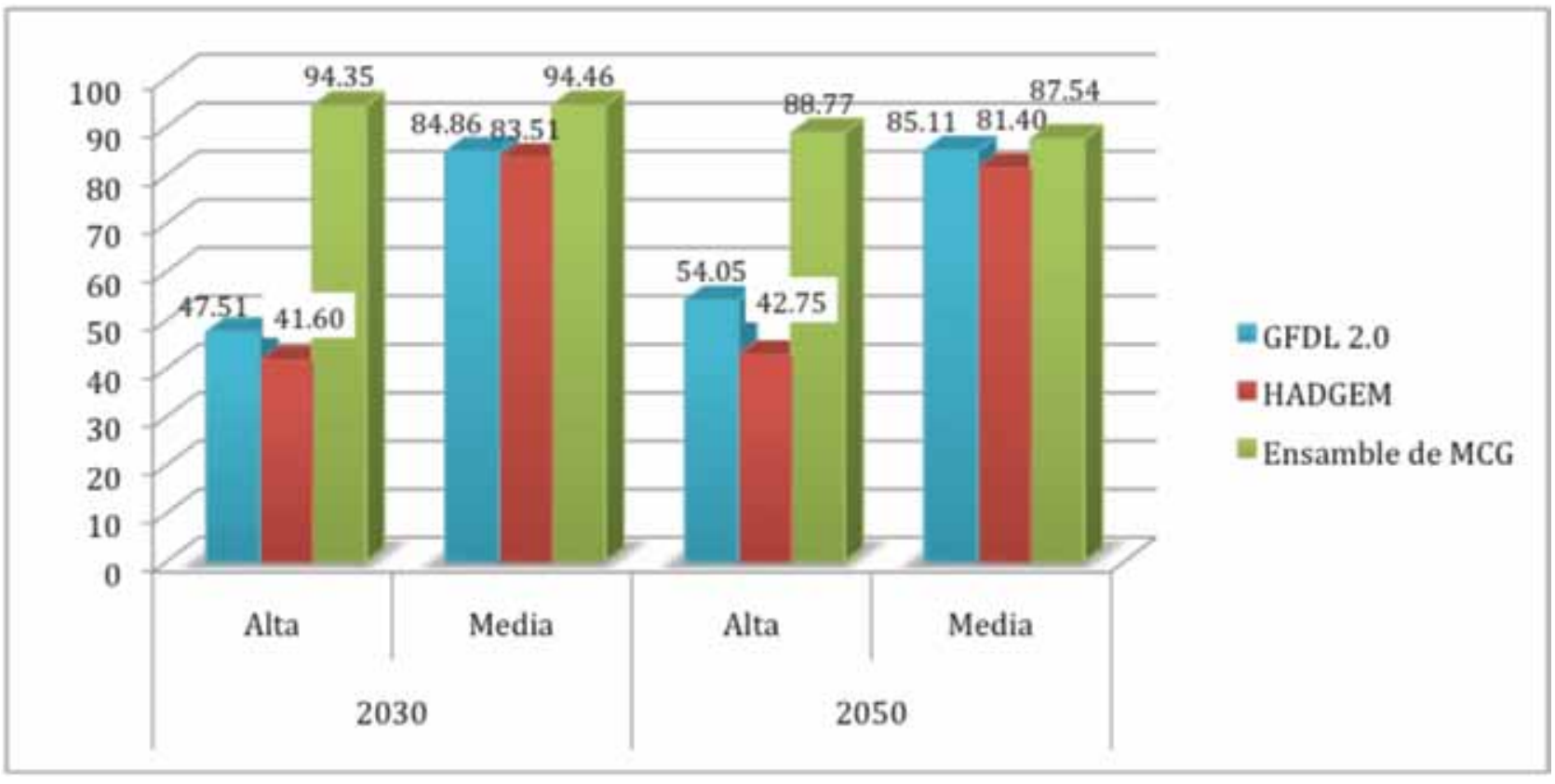

Figura 4. Porcentajes de aptitud del P. patula Schltdl. et. Cham. con escenarios de cambio climático tipo A2. Figure 4. Suitability percentages for Pinus patula Schltdl. et Cham. under A2 climate change scenarios. 
Pinus pseudostrobus posee una superficie importante de aptitud en el estado: una alta de 93425.40 ha lequivalente a $33.04 \%$ de la superficie forestal de coníferas del estado) y una media de 249 051.51 ha (equivalente a 88.07\%) (Cuadro 4).

La aptitud actual con nivel alto de $P$. pseudostrobus se distribuye escasamente en una frania central del estado que va de oriente a occidente. En el oriente se dispersa en regiones pequeñas localizadas desde la parte baja en áreas de agricultura de temporal hasta media alta en bosques secundarios de pino-encino y de pino. En la Sierra Monte Alto y Sierra de Las Cruces se ubica en áreas de bosques de encino, pino, oyamel y agricultura de temporal; en la vertiente sur y suroeste del Nevado de Toluca, en bosque de pino, pino-encino, oyamel y agricultura de temporal; en la Sierra Occidental, en bosque de pino-encino, oyamel y vegetación secundaria de oyamel y agricultura de temporal, y en la parte noroccidental, en bosque de encino y en agricultura de temporal (Figura 5).
Cuadro 4. Niveles de aptitud del terreno actual y con escenarios de cambio climático para Pinus pseudostrobus Lindl.

Table 4. Suitability levels of current surface and under climate change scenarios for Pinus pseudostrobus Lindl.

\begin{tabular}{lcc}
\hline Aptitud actual & Superficie apta (ha) & $\%$ \\
\hline Alta & 93425.40 & 33.04 \\
Media & 249051.51 & 88.07 \\
\hline
\end{tabular}

* Porcentaje respecto a la superficie forestal de coníferas.

* Per cent in regard to the soffwood forest area

it is mainly found in pine forests, secondary vegetation oak-pine forests, and rain-fed agriculture areas. In Valle de Bravo, it is located in pine, pine-oak and cloud forests, and in rain-fed agriculture areas. In the Sierra Occidental, it is found in pine, oak and fir forests, as well as in secondary vegetation fir forests and rain-fed agriculture areas. And in the northwestern and northern areas of the state, it is located in oak-pine, oak and pine-oak forests, and in rain-fed agriculture areas. Suitability levels with climate change scenarios are reported in Table 5.

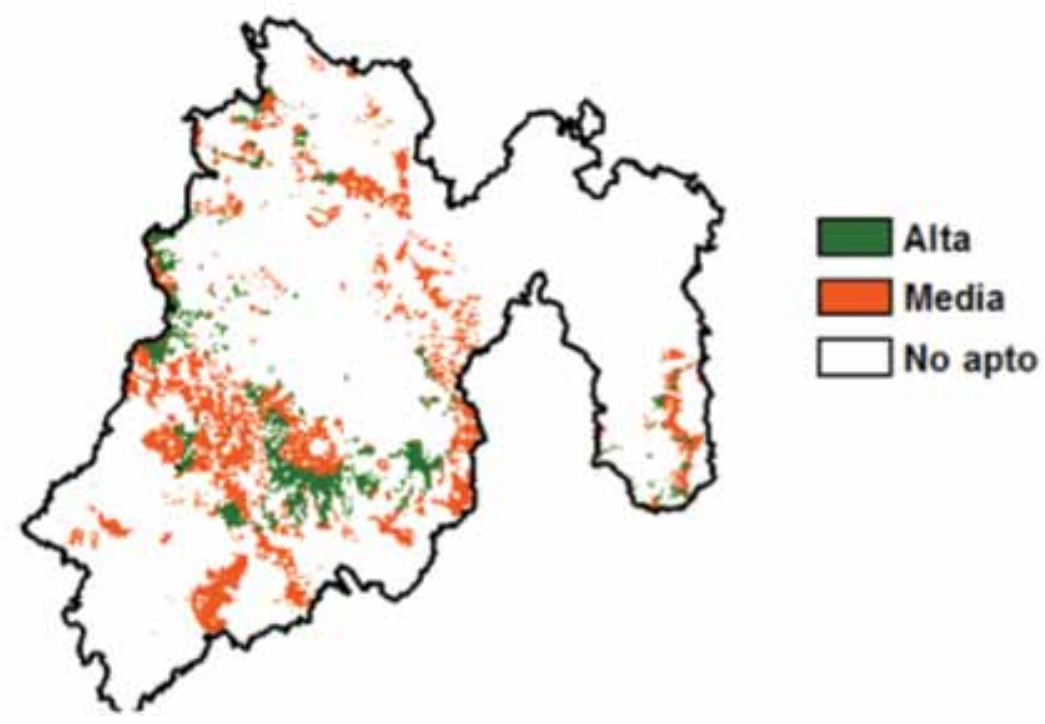

Figura 5. Distribución potencial actual de Pinus pseudostrobus Lindl.

Figure 5. Current potential distribution of P. pseudostrobus Lindl.

La distribución de la aptitud media es más amplia y abarca mayor área que la alta. En la parte oriental de la entidad se sitúa en bosques de pino, encino, y, en menor proporción, en terrenos de agricultura de temporal. En estos espacios presentan limitantes de profundidad del suelo y altitud y en algunos lugares el $\mathrm{pH}$. En la Sierra Monte Alto, en la Sierra de Las Cruces, y La Marquesa (región sur), se encuentra en bosques de oyamel, pino, encino-pino, mesófilo, encino y agricultura de temporal. En el Nevado de Toluca se halla principalmente sobre bosque de pino, bosques secundarios de pino-encino y agricultura de temporal; en Valle de Bravo, en bosques de pino, pino-encino, mesófilo y agricultura de temporal; en la Sierra Occidental, en bosque de pino-encino, oyamel, vegetación secundaria de oyamel y agricultura de
The suitability for $P$. pseudostrobus under A2 climate change scenarios shows several inconsistent surfaces. For 2030, the suitable extension using the GFDL 2.0 model has a wider surface than that resulting from the HADGEM model: $0.1 \%$ (seven ha). However, results are completely inconsistent with those provided by the ensemble of MCGs, since this model shows a result of $92.65 \%$ (86 555 ha), in contrast with the GFDL model. This also happens in the case of medium suitability; the difference between the results of the GFDL 2.0 and HADGEM models is $0.42 \%$ ( $1049 \mathrm{ha}$ ), and the contrast between the results of the GFDL 2.0 model and the ensemble of MCGs is $55.06 \%$ ( $137139 \mathrm{ha}$ ).

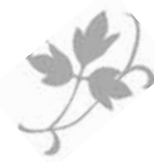


temporal, y en la zona noroccidental y norte, en bosque de encino-pino, encino, pino-encino y agricultura de temporal. Los niveles de aptitud con escenarios de cambio climático se consignan en el Cuadro 5.
For 2050, the highly suitable surface resulting from the use of the GFDL 2.0 model is wider than that from the HADGEM model: $0.28 \%$ (264 ha). Results are different with the ensemble of MCGs, since the asymmetry is of $90.40 \%$ (84 457 ha), in contrast

Cuadro 5. Superficie de aptitud de P. pseudostrobus Lindl. con escenarios de cambio climático tipo A2 (en hectáreas).

Table 5. Suitable surface for $P$. pseudostrobus Lindl. under A2 climate change scenarios (expressed in ha).

\begin{tabular}{|c|c|c|c|c|}
\hline Periodo & Aptitud & GFDL 2.0 & HADGEM & 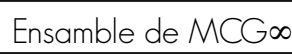 \\
\hline \multirow{4}{*}{2030} & Alta & 1626 & 1,619 & 88181 \\
\hline & $\%$ & 1.74 & 1.73 & 94.39 \\
\hline & Media & 97993 & 96944 & 235,132 \\
\hline & $\%^{*}$ & 39.35 & 38.93 & 94.41 \\
\hline \multirow{4}{*}{2050} & Alta & 1,904 & 1,640 & 86361 \\
\hline & $\% *$ & 2.04 & 1.76 & 92.44 \\
\hline & Media & 98707 & 97428 & 217984 \\
\hline & $\% *$ & 39.63 & 39.12 & 87.53 \\
\hline
\end{tabular}

$\infty$ Modelos de circulación general de la atmósfera; ${ }^{*}$ Porcentaje con la superficie actual.

$\infty$ Atmospheric general circulation models ${ }^{*}$ Per cent with the present area

La aptitud de P. pseudostrobus con escenarios de cambio climático del tipo A2 tiene diversas superficies dispares. Para el periodo 2030, la extensión de aptitud con el modelo GFDL 2.0 registra mayor superficie que con el HADGEM: $0.01 \%$ (siete hectáreas). No obstante, los resultados discrepan en su totalidad con Ensamble de MCG, ya que las diferencias son del orden de $92.65 \%$ (equivalente a 86555 ha) en relación al GFDL. Esto sucede también con la aptitud media entre GFDL 2.0 y HADGEM: 0.42\% (1 049 ha) y el contraste del GFDL 2.0 con Ensambles de MCG: 55.06\% ( $137139 \mathrm{ha}$ ).

Para el periodo 2050, la superficie de aptitud alta con el modelo GFDL 2.0 muestra mayor superficie que el HADGEM: 0.28\% (264 ha). Los resultados son distintos con el Ensamble de MCG, debido a que la asimetría es de $90.40 \%$ (equivalente a 84457 hal respecto al GFDL 20. Semejante situación se verifica con la aptitud media, pues entre GFDL 2.0 y HADGEM es de $0.51 \%$ (1,279 ha) y el contraste del GFDL 2.0 con Ensambles de MCG es de $47.90 \%$ ( 1119277 ha) (Figura 6).

La realidad es que el cambio climático afectará el desarrollo de las especies vegetales. En las plantas evaluadas, las proyecciones de los MCG presentan diferentes escenarios de precipitación y temperatura, los cuales reflejarán cambios en la distribución espacial actual. Para estas circunstancias, los resultados de P. patula y $P$. pseudostrobus con escenarios A2 del MCG GFDL 20 demuestran mayor superficie de aptitud que el HADGEM en las proyecciones de 2030 y 2050. No obstante, en ambos modelos las superficies apta alta y media de las especies forestales son mucho menores, comparadas con los modelos de Ensambles de MCG, debido a la resolución espacial y temporal que tienen los Ensambles, pues estos permiten realizar un mejor análisis a escala regional de las zonas más vulnerables (Magaña et al., 2007). to the results of the GFDL 2.0 model. Something similar happens with the medium suitability, since the difference between the results provided by the GFDL 2.0 and HADGEM models is of $0.51 \%(1,279 \mathrm{ha})$, and the contrast between those of the GFDL 2.0 model and the ensemble of MCGs is of $47.90 \%$ ( $1179277 \mathrm{ha}$ ) (Figure 6).

The reality is that climate change will affect the development of vegetable species. In the plants studied, the MCG projections show different rain fall and temperature scenarios, which reflect the changes in the current spatial distribution. Given these circumstances, the results for $P$. patula and $P$. pseudostrobus with A2 scenarios of the GFDL 2.0 MCG show a wider suitable surface than with the HADGEM model in projections for 2030 and 2050. However, highly and medium forest suitable surfaces are smaller in comparison to the results expressed using the ensemble of MCGs, due to the spatial and temporal resolution of the ensembles, which allow for a better analysis of the most vulnerable zones at regional level (Magaña et al., 2007).

The results of the land suitability studies depend on several factors, such as the application of MCGs, the scenarios, the methodology, and the spatial and temporal resolution.

The ensemble of MCGs made for carrying out potential distribution projections of biological species provides more detailed results than MCGs due to its high resolution. The larger scale shows a higher representativeness of the environmental factors involved in the plant development in the field.

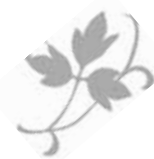




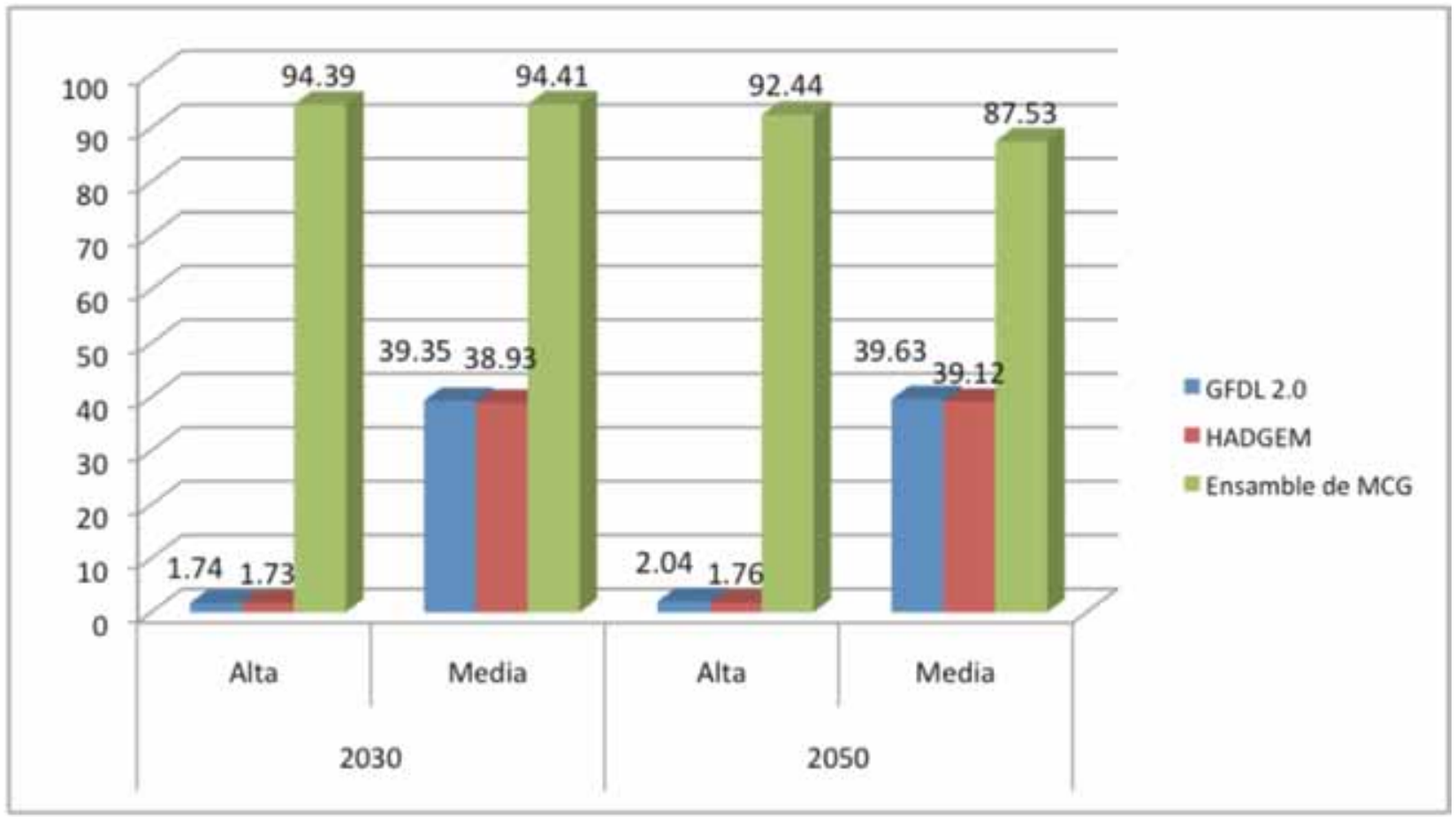

Figura 6. Porcentajes de aptitud del P. pseudostrobus Lindl. con escenarios de cambio climático tipo A2.

Figure 6. Suitability percentages for P. pseudostrobus Lindl. with A2 climate change scenarios.

Los resultados de estudios de aptitud del terreno dependen de varios factores, como la aplicación de los MCG, escenarios, metodología, resolución espacial y temporal.

El Ensamble de MCG para llevar a cabo proyecciones de distribución potencial de especies biológicas, pues a causa de su alta resolución genera resultados con mayor detalle que los MCG. La escala más grande presenta mayor representatividad de los factores ambientales que intervienen en el desarrollo de las plantas en el terreno.

\section{CONCLUSIONES}

La distribución potencial de Pinus patula y Pinus pseudostrobus en el Estado de México con escenarios de cambio climático tiende a reducirse de manera importante. No obstante, la primera especie proyecta mayor superficie de distribución.

\section{REFERENCIAS}

Comisión Nacional para el Conocimiento y Uso de la Biodiversidad (Conabio)-Programa Nacional de Reforestación (Pronare) 2006. Sistema de Información para la Reforestación. SIRE. Comisión Nacional para el Conocimiento y Uso de la Biodiversidad. Programa Nacional de Reforestación Paquetes tecnológicos. Especies varias. http:// 148.223. 105. 188:2222/ gif/snif_ portal/index.php? option= com _ content\&task=view\&id=23\&lt emid=24. (octubre a noviembre de 2011).

\section{CONCLUSIONS}

The potential distribution of $P$. patula and $P$. pseudostrobus in Estado de Mexico under climate change scenarios tends to be significantly reduced. However, the former is projected to have a larger distribution.

End of the English version

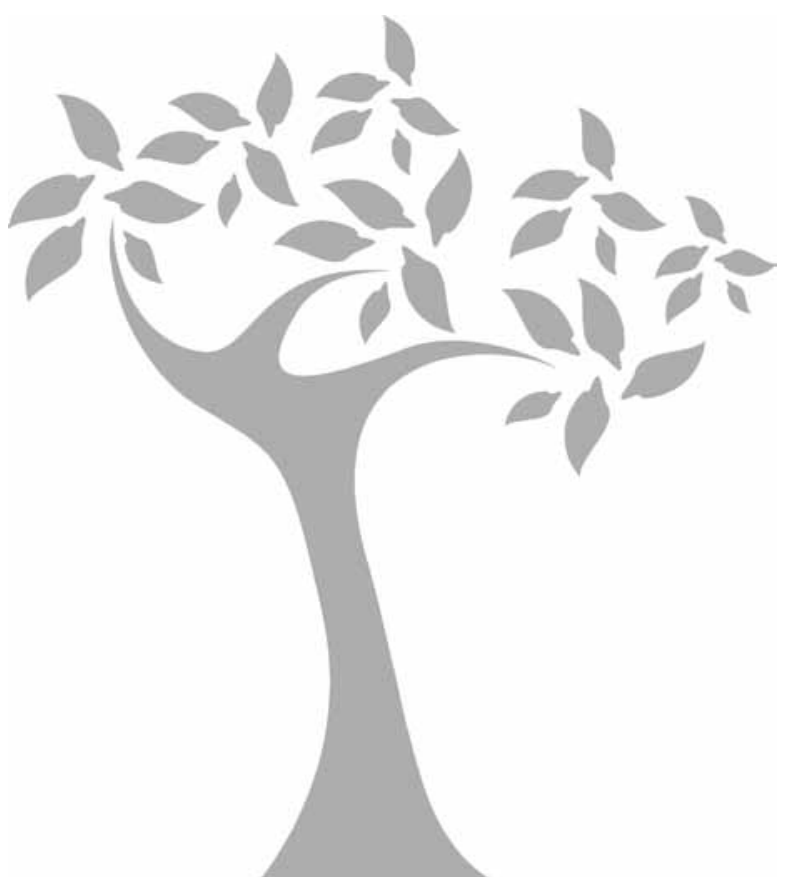


Rev. Mex. Cien. For. Vol. 4 Núm. 15

Conde, C., B. Martínez, O. Sánchez, F. Estrada, A. Fernández, J. Zavala y C. Gay. 2008. Escenarios de cambio climático (2030 y 2050) para México y Centro América. Temperatura y precipitación. http://www. atmosfera.unam.mx/gcclimatico/index.php?option=com _ content\&vie w=article\&id=61 \&ltemid=74. (11 de agosto de 2009).

Convención Marco de las Naciones Unidas sobre el Cambio Climático (UNFCCC). 2007. Unidos por el clima. Guía de la Convención sobre el Cambio Climático y el Protocolo de Kyoto. Bond, Alemania. 40 p.

Dale, V. H., L. A. Joyce, S. McNulty, R. P. Nielson, M. P. Ayres, M. D. Flannigan, P. J. Hanson, L. C. Irland, A. E. Lugo, C. J. Peterson, D. Simberloff, F. J. Swanson, B. J. Stocks and B. M. Wotton.2001. Climate change and forest disturbances. Biosciences. 51 (9):723-734.

Delgado, T. y D. Suárez D. 2009. Efecto del cambio climático en la diversidad vegetal del corredor de conservación comunitaria Reserva Ecológica El Angel-Bosque Protector Golondrinas en el Norte de Ecuador. Ecología Aplicada. 8 (2):27-36.

Díaz, G. 2007. Potencial agroproductivo de especies forestales en México. In: Fernández, R., C. Ortiz, M. Reyes, F. de J. Legorreta P. y G. García. Reporte anual de investigación e innovación tecnológica. INFAP. México, D. F. México. 304 p.

Eguiluz, T. 1978. Ensayo de integración de los conocimientos sobre el género Pinus en México. Universidad Autónoma de Chapingo. Depto. de Enseñanza, Irvestigación y Servicio en Bosques. Chapingo, Edo. de Méx. México. 623 p.

Gillespie, A. J. R. 1992. Pinus patula Schiede \& Deppe: Patula pine. SO-ITFSM-54 Departament of Agriculture, Forest Service. Southern Forest Experiment Station. New Orleans, LA USA. 5 p. http://www.fs.fed.us/ global/iitf/Pinuspatula.pdf (27 de marzo de 2012).

Gómez D., J. D., A. I. Monterroso R. y J. A. Tinoco R. 2007. Distribución del cedro rojo (Cedrela odorata L.) en el estado de Hidalgo, bajo condiciones actuales y escenarios de cambio climático. Maderas y Bosques. 13(2): 29-49.

Gómez C., L. M. 2009a. Localización de áreas potenciales para reforestación de una área natural protegida en el Estado de México. Tesis profesional. Universidad Autónoma Chapingo. Chapingo, Edo. de Méx. México. 56 p.

Gómez D., J. D., A. I. Monterroso R., J. A. Tinoco R. y M. L. Toledo R. 2009b. Cuarta Comunicación Nacional de México ante la Convención Marco de Naciones Unidas sobre el Cambio Climático: Sector forestal. Instituto Nacional de Ecología, Secretaría de Medio Ambiente y Recursos Naturales; Centro de Ciencias de la Atmósfera, Universidad Nacional Autónoma de México; Departamento de Suelos, Universidad Autónoma Chapingo. Chapingo, Edo. de Méx. México. 93 p.

Instituto Nacional de Estadística, Geografía e Informática (INEGI). 2005. Carta de Uso Actual del Suelo y Vegetación. Serie III. Escala. 1:250 000. México. s/p

Instituto Nacional de Estadística, Geografía e Informática (INEGI). 2007. Anuario Estadístico. México. Tomo l. Aguascalientes, Ags. México. 576 p.

Instituto Nacional de Estadística, Geografía e Informática (INEGI). 2008. Anuario Estadístico. México. Tomo I. Aguascalientes, Ags. México. 532 p.

Instituto Nacional de Estadística, Geografía e Informática (INEGI). 2010. Conjunto Nacional de Uso del Suelo y Vegetación a escala 1:250 000, Serie IV. DGG-INEGI. México. s/p

Instituto Nacional de Investigaciones Forestales, Agrícolas y Pecuarias (INFAP) y Comisión Nacional para el Conocimiento y Uso de la Biodiversidad (CONAB|O). 1995. Mapa edafológico. Escala 1:250 000 y 1:1000000 México. s/p

Intergovernmental Panel on Climate Change (PCC). 2007. Climate Change 2007: The physical science basis. Contribution of Working Group $\|$ to the Third Assessment Report of the Intergovernmental Panel on Climate Change. S. Salomon, D. Oin, M. Manning, Z. Chen, M. Marquis, K. B. Averty, M. Tignor and H. L. Miller (eds.). Cambridge University Press Cambridge, United Kingdom and New York, NY USA. 996 p.
Iverson, L. R., A. Prasad and M. W. Schwartz. 1999. Modeling potential future individual tree-species distributions in the Eastern United States under climate change scenario: a case study with Pinus virginiana. Ecological Modelling 115: 77-93.

Magaña, V., C. Conde A., O. Sánchez y C. Gay G. 2000. Evaluación de escenarios regionales de clima actual y de cambio climático futuro para México. In: Gay. C. 2003. México: Una visión hacia el siglo XXI. El cambio climático en México. Instituto Nacional de Ecología, UNAM. México, D.F. México. pp. 1-18.

Magaña R., V., C. Conde, O. Sánchez and C. Gay. 2007. Assessement of current and future regional climate scenarios for Mexico. Climate Research. 9 (2): 107-114.

Magaña R., V. O. 2010. Guía para generar y aplicar escenarios probabilísticos regionales de cambio climático en la toma de decisiones. Instituto Nacional de Ecología, Embajada Británica en México y Tecnológico de Monterrey. México, D. F. México. 97 p.

Monterroso R, A. I., J. D. Gómez D. and J. A. Tinoco R. 2010. Potential distribution of two dominant species in the National Park "Nevado de Toluca", central México, current and future climate change scenarios. Journal of Environmental Sciences 1 (1):27-34.

Pérez, N., A. Ferré, J. Carreras y X. Font. 2011. Efecto del cambio climático sobre la distribución potencial de los hábitats subalpinos y alpinos del Pirineo catalán y andorrano. In: Ninot, J. M., E. Carrillo, X. Font, I. Soriano, J. Valès, M. Domènech y M. Niell. Monografies del Cenma Botánica Pirenaico-cantábrica. Actes del IX Col-loqui Internacional de Botánica Pirenaico-Cantábrica a Ordino. Ordino, Andorra. pp. 329-341.

Programa de las Naciones Unidas para el Medio Ambiente (PNUMA). 2005. Cambio climático. Manual de Ciudadanía Ambiental Global. Oficina Regional para América Latina y el Caribe. México, D. F. México. $33 \mathrm{p}$.

Protectora de Bosques. 2006. Programa de desarrollo forestal sustentable del Estado de México 2005-2006. Secretaría de Desarrollo Agropecuario. Gobierno del Estado de México. Metepec, Edo. de Méx., México. 100 p.

Root, T. L., J. T. Price, K. R. Hall, S. H. Schneider, C. Rosenzeig and J. A. Pounds. 2003. Fingerprints of global warming on wild animals and plants. Nature. 421:57-60.

Sedjo, R. A. 2010. Adaptation of forests to climate change: some estimates. Resources for the future. Washington, D. C. USA. 51 p. http://www.rff. org/RFF/Documents/RFF-DP-10-06.pdf (3 de marzo de 2012).

Sims, R. E. H. R. N. Schock, A. Adegbululgbe, J. Fenhann, I. Konstantinaviciute, W. Moomaw, H.B. Nimir, B. Schlamadinger, J. Torres M. C. Turner, Y. Uchiyama, S. J. V. Vuori, N. Wamukonya and X. Zhang. 2007. Energy supply. In: Metz, B., O. R. Davidson, P. R. Bosch, R. Dave and L. A. Meyer (eds.). Climate change: Mitigation. Contribution of Working Group III to the Fourth Assessment Report of the Intergovernmental Panel on Climate Change. Cambridge University Press. Cambridge, U K /New York, NY, USA. pp. 251-322.

Spittlehouse, D. L. and R. B. Stewart. 2003. Adaptation to climate change in forest management. BC Journal of Ecosystems and Management 4 (1): 1- 11 .

Stead, J. W. 1983. A study of variation and taxonomy of the Pinus pseudostrobus complex. Commonwealth Forestry Review 62 (1):25-35.

Trejo, I., E. Martínez M. E. Calixło P., S. Sánchez C., R. Vázquez T. and L. Villers R. 2011. Analysis of the effects of climate change on plant communities and mammals in México. Atmósfera 24 (1): 1- 14.

Villers R., L. and L. Trejo V. 1998. Climate change on Mexican forests and natural protected areas. Global Environmental Change 2 (8): 141- 157.

Viveros, V. H., C. Sáenz R., J. J. Vargas H. y J. López U. 2006. Variación entre procedencias de Pinus pseudostrobus establecidas en dos sitios de Michoacán, México. Revista Fitotecnia Mexicana 29 (2): 121-1.

Zonneveld, M., J. Koskela, B. Vicenti y A. Jarvis. 2009. Repercusiones del cambio climático en la distribución de los pinos tropicales en Asia sudoriental. Unasylva 231/232 (60): 24-28. 